\title{
AWARENESS AND USE OF CURRENT SPORTS INJURY PREVENTION PROGRAMS AMONG PHYSIOTHERAPISTS WORLDWIDE
}

\author{
Wesam Saleh A. Al Attar ${ }^{1,2,3 \mathrm{ABCDE}}$, Saud Alarifi ${ }^{4 \mathrm{CD}}$, Hussain Ghulam $^{5 \mathrm{CD}}$, \\ Sameer Yamani ${ }^{1 \mathrm{BD}}$, Eyad Alharbi ${ }^{1 \mathrm{BD}}$, Majed Aljabri ${ }^{1 \mathrm{BD}}$, Ross H. Sanders ${ }^{2 \mathrm{AD}}$ \\ ${ }^{1}$ Umm Al Qura University \\ ${ }^{2}$ The University of Sydney \\ ${ }^{3}$ University of Basel \\ ${ }^{4}$ King Abdulaziz Medical City \\ ${ }^{5}$ Najran University \\ Authors' Contribution: A - Study design; B - Data collection; C - Statistical analysis; D - Manuscript Preparation; E - Funds Collection
}

Corresponding Author: Wesam Saleh A. Al Attar, E-mail: wsattar@uqu.edu.sa

Accepted for Publication: November 6, 2021

Published: December 25, 2021

DOI: 10.17309/tmfv.2021.4.12

\begin{abstract}
Purpose. Physiotherapists are trained to prevent, assess, and rehabilitate all kinds of injuries including sports injury. The goal of the physical physiotherapist should be making sure that the athlete is in optimal shape to perform, with a minimal risk for developing an injury. This study aims to assess the physiotherapists' awareness, implementation, and views of sports injury prevention programs (IPPs) from an international perspective.

Materials and methods. A self-administered questionnaire was developed and distributed to physiotherapists worldwide through World Physiotherapy member organizations. The study targeted physiotherapists at an international level. The study included 484 participants, of whom $44.4 \%$ were male and $55.6 \%$ were female physiotherapists.

Results. A total of 287 (59.3\%) of the participants were aware of the current sports IPPs, 177 (36.6\%) were implementing sports IPPs in their current practice. Participants who implemented the sports IPPs reported a positive opinion about the program efficacy, with a score of $7.3 \pm 2.11$ out of 10 .

Conclusions. Globally, physiotherapists have average awareness and low implementation levels of IPPs.

Physiotherapists showed a positive score regarding the effectiveness of IPPS, especially the KIPP and the iSPRINT.

Keywords: athletes, injuries, sports, physical therapy, surveys and questionnaires, internationality.
\end{abstract}

\section{Introduction}

A real growing interest in the sports industry is currently being witnessed globally, attributable to a highly profitable and competitive nature. As a result, many athletes try to reach the high-standard, professional level of elite professional sport. However, one of the challenges they may have to contend with is sustaining an injury through either contact or non-contact sports. These injuries may be acute, occurring suddenly, or due to repeated actions, known as overuse injuries (Dhillon et al., 2017). Case history data of all adolescents presenting to sports clinics in Europe due to sports injuries, spanning over ten years, was systematically recorded

(C) Al Attar, W.S.A., Alarifi, S., Ghulam, H., Yamani, S., Alharbi, E., Aljabri, M., \& Sanders, R.H., 2021. on a purpose-built software program (Habelt et al., 2011). A total of 17,397 individuals sought treatment, from 19,530 injuries. Just over one-quarter of all injuries $(25.68 \%, 4,468)$ were in those aged between $10-19$ years. Over one third were males $(66.97 \%)$, and $32.88 \%$ were females, while the remaining $0.16 \%$ were classified as other gender categories (Habelt et al., 2011). Soccer was the most common cause of injury (31.13\%), reflecting general popularity throughout Europe. Handball, school sport-related activities, skiing, and biking accounted for $8.89 \%, 8.77 \%, 5.95 \%$, and $5.71 \%$ of other injuries, respectively (Habelt et al., 2011). Most injuries occurred in the lower limbs (68.71\%), followed by the upper limbs $(25.27 \%)$, with the spine and head being injured in $2.57 \%$ and $1.99 \%$ of the cases, respectively. Upper extremity injuries occurred in all areas, but fingers, metacarpus, and wrist injuries were the most common accounting for $8.12 \%, 3.13 \%$, and 
$3.54 \%$, respectively. Knee (29.79\%) and ankle joint (24.02\%) injuries were most common in lower extremities. In contrast, injuries to the shoulder (5.42\%) and elbow joint (2.84\%) were the lower occurrences (Habelt et al., 2011).

Currently, athletes who are engaged in competitive sports are getting injured frequently, and they may feel compelled to return to their activity without delay. Such pressure may emanate from themselves or their management team. Within the context of a highly competitive sporting environment, inevitably the fear of losing their place on the team may spur them into resuming activity more quickly (Dhillon et al., 2017). The length of recovery time required being away from a competitive play or training is usually a good indicator of the injury's severity (Ekegren et al., 2015). This can range from a non-reportable injury where no time off is required, to severe injury leading to a permanent absence, with minor losses (1-7 days), moderate losses (8-21 days), and severe losses (over 21 days) occurring along this continuum (Ekegren et al., 2015). Other elements can also be taken into account when classifying the injury severity. This will help determine remediation time, sick leave days and cost of remediation (Patel et al., 2017).

Rehabilitation following a sports injury plays an essential role in supporting a full recovery and reducing the length of absence after injury. Moreover, rehabilitation aims to prevent re-injury in the future. While every effort is made to ensure that the athlete can return to play (RTP) at the earliest possible opportunity, with sports clinicians carefully overseeing this safe transition process, ultimately, the athlete makes the final decision for readiness to return (Dhillon et al., 2017). A number of measures may be recommended to ensure that athletes return to their previous fitness levels while remaining injury-free. These measures include surgery, pharmacological interventions, use of dietary supplements, and psychological support. However, regardless of the treatment provided, the rehabilitation plays a key role in the recovery process (Dhillon et al., 2017).

Sports Injury prevention programs (IPPs) have several benefits. These include minimizing the likelihood of injury occurrence, promoting athletes' health and fitness levels, enhancing performance potential, and decreasing the costs associated with medical care. There is strong evidence to indicate that a previous injury increases the likelihood of re-injury (Dhillon et al., 2017). Consequently, this highlights the benefits of ensuring that athletes are monitored carefully, resuming full participation in their sporting activities (Dhillon et al., 2017). Furthermore, a meta-analysis examining IPPs among an adolescent cohort participating in team sports found that IPPs significantly reduced injury rates (Soomro et al,. 2016). As a result, these programs have attracted significant attention within the field of sports medicine in recent years (Al Attar et al., 2015). In addition, several IPPs have been implemented to either prevent entirely or minimize the risk of acquiring severe injuries (Patel et al., 2017). The current study has selected eleven such programs to assess physiotherapists' awareness, implementation, and opinions.

As the lead agency, the Federation Internationale Football Association (FIFA) Medical Assessment and Research Centre worked in partnership with the Oslo Sports Trauma Research Center and the Santa Monica Orthopaedic and Sports Medicine Center to develop an IPP known as the FIFA 11+, which was launched in 2006 (Al Attar et al., 2017; Sadigursky et al., 2017). It is easy to implement a three-stage program containing a comprehensive warm-up activity procedure and 15 structured exercises that follow a particular sequence (Sadigursky et al., 2017). A review of the program highlighted that the recommended activities could be classified into three broad types: running and active stretching; core and leg strengthening; and high-speed planting and cutting tasks (Al Attar \& Alshehri, 2019). The program places particular focus on the importance of carrying out the techniques outlined correctly. Accordingly, it has set out how to ensure that good posture and body control are maintained, particularly, with smooth landings, knee-over-foot tip positioning, and leg alignment (Sadigursky et al., 2017). A systematic review was undertaken to assess the FIFA 11+ program's effectiveness in the prevention of injuries in a mixed-gender cohort of soccer players, who were aged 13 years or older (Sadigursky et al., 2017). All the studies selected for inclusion are randomized clinical trials. That was the first systematic review to do so. Results revealed that the warm-up program reduced injury risk by $30 \%$ in soccer players.

The FIFA 11+ Kids IPP's primary aim is to prevent and minimize both the frequency and level of severity of football injuries. This is achieved by implementing several evidencebased activities, which seek to improve basic and specific sportsrelated motor skills in young athletes (Pomares-Noguera et al., 2018). Therefore, the program places particular emphasis on three key areas. The first area is spatial orientation, anticipation, and attention, where players are required to perform two tasks simultaneously while avoiding contacting other players or objects unintentionally. The second area involves general coordination of the movement as opposed to neuromuscular or proprioceptive training, as well as body stability. Third, the program teaches players specific fall techniques to reduce the potential risks associated with unavoidable falls (PomaresNoguera et al., 2018). Research undertaken involving one large cluster-randomized controlled trial sought to determine this program's effectiveness (Pomares-Noguera et al., 2018). They reported a $38 \%$ reduction in injuries among the target cohort, while severe injuries were found to decrease by more than $50 \%$ compared to the control group.

Developing the FIFA 11+ Referees, IPP was an acknowledgement of modern game football refereeing demands, particularly for those working with elite athletes. Consequently, they may be more susceptible to lower extremity injuries due to heavy training regimes and match schedules (Bizzini \& Dvorak, 2015). Analysis of injury data for this specific cohort, used in combination with the learning from the already well-establish FIFA 11+ program, led to the development and pilot testing of the FIFA 11+ Referees' IPP for referees and assistant referees (Bizzini \& Dvorak, 2015). It was subsequently launched in 2013 and has now been integrated into the FIFA refereeing training courses. More recently, the Italian Referee Association has begun a study to assess its effects on match officials, officiating in games ranging from high to low level (Bizzini \& Dvorak, 2015).

In Ireland, the Gaelic Athletic Association (GAA) is the country's largest sporting organization. An amateur association actively promotes indigenous games, particularly Gaelic football, and hurling (a stick and ball sport) (O'Malley et al., 2017). The program included a 15 -minute injury prevention warm-up program known as the GAA 15 (Galic Atheltic Association, 2015). This program's dual advantages are that 
it can be integrated into existing training regimes without additional equipment to carry out these activities. A well-established partnership formed in 2006 between the GAA Medical, Scientific, and Welfare Committee and physiotherapy department in the University College Dublin is continuing to support the preparation of a framework for injury prevention among GAA players (Galic Atheltic Association, 2015).

Before developing the FIFA 11 program, some researchers and athletes implemented a program known as the Prevent Injury and Enhance Performance (PEP) (Rahnama, 2012). It comprises a range of activities, including warmups, stretching, and strengthening exercises, plyometrics, and agility skills which seek to remedy any potential weaknesses in terms of the strength and coordination capability of stabilizing muscles surrounding the knee joint (Santa Monica Sports Medicine Research Foundation, 2011). Ideally, this program should be implemented three times weekly and usually requires 15-20 minutes to fully complete. However, novice users may need additional time to become more familiar with their content and the transitioning process (Santa Monica Sports Medicine Research Foundation, 2011). It is also recommended that athletes aged twelve years or younger should carry out their plyometric exercises over a visual line placed on the field or the flat 2" cone, were following each jump they would land on both feet. It was also advised not to undertake single leg plyometrics with young athletes until such time, as they can demonstrate that they have established substantial control (Santa Monica Sports Medicine Research Foundation, 2011). The PEP has been found to produce direct positive outcomes in reducing anterior cruciate ligament (ACL) injury rates among female football players (Rahnama, 2012). Similarly, it was also shown to effectively prevent or reduce injury in a wider general population (Yarsiasat et al., 2019).

Focusing on neuromuscular training (NMT), the Knee IPP (KIPP) integrates various skills. These include progressive strengthening, balance, plyometrics, and agility exercises, creating awareness of the importance of avoiding dynamic knee valgus, associated with increased ACL injury risk. It also highlights that activities such as landing from jumps with flexed hips and knees will decrease ACL-related strain (LaBella et al., 2011). The program is normally led by a coach and requires 20 minutes to complete in full. Implementing the KIPP as part of either preseason or in-season warm-ups decreased lower extremity injuries in female adolescent soccer and basketball players (LaBella et al., 2011).

Compared to other international sports, rugby players demonstrated a higher injury risk (Sewry et al., 2017a,b). In response to this, the South African Rugby Union (SARU) devised and introduced BokSmart, an evidence-based program that sought to reduce injury-related burden (Sewry et al., 2017). An evaluation of this program was also revealed to prevent injuries from occurring in the first instance, reducing the overall injury rate (Sewry et al., 2017). A further benefit was found to reduce the risk of junior South African team members who sustain a catastrophic injury (Sewry et al., 2017). These positive outcomes led to further development of the BokSmart program, whereby the safe six programs were introduced in 2014 (Sewry et al., 2017), which is an IPP, including six targeted exercises. While the exercises are fairly demanding, overall, the program is relatively easy to carry out and could, potentially, be integrated into a warm-up regime. It can be undertaken within a reasonably short period, and it does not require any specific equipment. It is focused specifically on joint stability, strength, achieving balance, and control skills (Sewry et al., 2017).

In Sweden, a commercial IPP, known as the Knäkontroll, was specifically designed in 2005 to aid coaches involved in team sports with children and adolescents (Hägglund et al., 2009). It includes six structured warm-up exercises, which concentrated on core stability and neuromuscular knee control (Hägglund et al., 2009).

The iSPRINT is an NMT warm-up program of fifteenminute duration. It contains a range of exercises that focus on agility, strength, balance, and aerobic skills (Voight \& Esculier, 2019). It has been recommended as the best practice in injury prevention among younger athletes involved in sport and recreational (S\&R) activities (Voight \& Esculier, 2019).

The Accident Compensation Corporation (ACC) aims to decrease the frequency as well as the severity of sport-related injuries (ACC SportSmart 2016). In order to achieve this, they have to work closely in partnership with various sporting organizations to devise and introduce a range of injury prevention approaches (ACC SportSmart 2016). For example, in New Zealand, the ACC SportSmart framework was developed, along with accompanying resource material. Their primary goal was to ensure that the advice they provided becomes integrated into practice, thus reducing the likelihood of injury occurring for those who were involved in organized sports (ACC SportSmart 2016). A further associated advantage was performing to the highest possible level (ACC SportSmart 2016). This framework also identifies specific populations with particular injury prevention requirements, namely, young people, older people, females, and those with physical or intellectual disability (ACC SportSmart 2016). It was also noticed individuals to other organizations may provide additional information and support (ACC SportSmart 2016).

Given the complex interaction of multiple risk factors associated with sports injuries, no single intervention or approach will be sufficient to address these problems. Therefore, a number of different strategies need to be adopted to ensure that sports safety frameworks are implemented effectively and take various multidimensional aspects into account. Therefore, this study aims to assess physiotherapists' awareness, implementation, and opinion of sports IPPs, from an international perspective.

\section{Materials and methods}

\section{Study design and questionnaire}

This study utilized a repeated measures design to survey worldwide physiotherapists' in IPPS. The study authors developed the questionnaire to collect information about the awareness, knowledge, of worldwide physiotherapists' in IPPS. To our knowledge, no validated questionnaires addressed physiotherapists' experience with IPPs. The survey was distributed to physiotherapists' who were felt to represent the final testing cohort due to their varying experience. Each question was rated by external validation for clarity, comprehension, and appropriateness on a scale of 1 to 5 . Questions scoring an average below 4.0 on any of the parameters were discarded; however, all questions scored 5 and were considered suitable for this study. The study was 
Table 1. Participant Characteristics

\begin{tabular}{|c|c|}
\hline Indicators & Frequency $(\%)$ \\
\hline \multicolumn{2}{|c|}{ World Confederation for Physiotherapy Regions } \\
\hline $\begin{array}{l}\text { Europe } \\
\text { South American } \\
\text { Asia } \\
\text { Africa } \\
\text { North, Central America and } \\
\text { Caribbean } \\
\text { Oceania }\end{array}$ & $\begin{array}{c}205(42.4 \%) \\
15(3.1 \%) \\
169(34.9 \%) \\
27(5.6 \%) \\
48(9.9 \%) \\
20(4.1 \%) \\
\end{array}$ \\
\hline $\begin{array}{l}\text { Gender } \\
\text { Male } \\
\text { Female } \\
\end{array}$ & $\begin{array}{l}215(44.4 \%) \\
269(55.6 \%) \\
\end{array}$ \\
\hline $\begin{array}{l}\text { Age group } \\
18-25 \\
26-30 \\
31-35 \\
36-40 \\
41-45 \\
46-50 \\
51-55 \\
56-60 \\
61+\end{array}$ & $\begin{array}{c}62(12.8 \%) \\
120(24.8 \%) \\
117(24.2 \%) \\
84(17.4 \%) \\
38(7.9 \%) \\
22(4.5 \%) \\
24(5.0 \%) \\
10(2.1 \%) \\
7(1.4 \%)\end{array}$ \\
\hline $\begin{array}{l}\text { Experience (Years) } \\
<6 \\
6-10 \\
11-15 \\
16-20 \\
21-25 \\
26-30 \\
31-35 \\
36-40 \\
41+\end{array}$ & $\begin{array}{c}165(34.1 \%) \\
124(25.6 \%) \\
78(16.1 \%) \\
54(11.2 \%) \\
25(5.2 \%) \\
15(3.1 \%) \\
12(2.5 \%) \\
7(1.4 \%) \\
4(0.8 \%)\end{array}$ \\
\hline $\begin{array}{l}\text { Title } \\
\text { Professor } \\
\text { Associate Professor } \\
\text { Assistant Professor } \\
\text { Lecturer } \\
\text { Demonstrator } \\
\text { Consultant } \\
\text { Senior Specialist } \\
\text { Specialist } \\
\text { Technician } \\
\text { Intern }\end{array}$ & $\begin{array}{c}9(1.9 \%) \\
11(2.3 \%) \\
20(4.1 \%) \\
23(4.8 \%) \\
6(1.2 \%) \\
27(5.6 \%) \\
107(22.1 \%) \\
210(43.4 \%) \\
53(11.0 \%) \\
18(3.7 \%)\end{array}$ \\
\hline $\begin{array}{l}\text { Specialized (Sports) } \\
\text { Yes } \\
\text { No }\end{array}$ & $\begin{array}{l}195(40.3 \%) \\
289(59.7 \%)\end{array}$ \\
\hline $\begin{array}{l}\text { Degree } \\
\text { B.Sc. } \\
\text { Dip } \\
\text { DPT } \\
\text { M.Sc. } \\
\text { PhD } \\
\text { PT Fellow }\end{array}$ & $\begin{array}{c}130(26.9 \%) \\
58(12.0 \%) \\
61(12.6 \%) \\
160(33.1 \%) \\
36(7.4 \%) \\
39(8.1 \%)\end{array}$ \\
\hline
\end{tabular}

$\mathrm{PhD}=$ Doctor of Philosophy; $\mathrm{MSc}=$ Master of Science; $\mathrm{PT}$ Fellow $=$ Physiotherapy Fellowship; DPT $=$ Doctor of Physiotherapy; BSc $=$ Bachelor of Science; Dip = Diploma

a cross-sectional survey that targeted physiotherapists from different countries. This survey consisted of 10 questions covering physiotherapists' socio-demographics, including gender, age, if they are specialized in sports medicine, years of experience, highest educational degree, main job, and the country. The second section was about awareness, where participants were asked if they are aware of the eleven
IPPS. The third section was about the implementation. Participants who reported implementing IPP were asked about their opinion regarding IPP effectiveness in the prevention of injuries on a 10-points Likert scale of 1 (ineffective) to 10 (very effective). The Biomedical Ethics Committee at Umm Al Qura University reviewed and approved the study. Approval No. (HAPO02K012202011497). All participants in this study provided consent to take part in the study.

\section{Survey software and administration}

The survey was uploaded to recognized online survey software (Survey Monkey SurveyMonkey Inc. San Mateo, California, USA). Respondents were provided with the link, and once a respondent had submitted the survey, they could not respond again. Results were compiled using the Survey Monkey software. All responses were voluntary, anonymous, confidential, and for research purposes only. Responses were collected from September 2018 to April 2020.

\section{Sample Size and Statistical analysis}

There are 625,000 physiotherapy members in the World Physiotherapy around the world (World Physiotherapy 2020 ). Considering a $5 \%$ margin of error at a $95 \%$ confidence level, the target number of physiotherapists was 384

Table 2. Awareness and implementation

\begin{tabular}{lc}
\hline \multicolumn{1}{c}{ Indicators } & Frequency (\%) \\
\hline Awareness & \\
$11+$ & $219(45.2 \%)$ \\
$11+\mathrm{K}$ & $102(21.1 \%)$ \\
$11+\mathrm{R}$ & $59(12.2 \%)$ \\
$11+\mathrm{S}$ & $76(15.7 \%)$ \\
GAA15 & $31(6.4 \%)$ \\
PEP & $68(14.0 \%)$ \\
KIPP & $102(21.1 \%)$ \\
Boksmart & $15(3.1 \%)$ \\
Knäkontroll & $11(2.3 \%)$ \\
iSPRINT & $18(3.7 \%)$ \\
ACC & $23(4.8 \%)$ \\
N/A & $197(40.7 \%)$ \\
Implementation & \\
$11+$ & $108(22.3 \%)$ \\
$11+\mathrm{K}$ & $37(7.6 \%)$ \\
$11+\mathrm{R}$ & $18(3.7 \%)$ \\
$11+S$ & $41(8.5 \%)$ \\
GAA15 & $15(3.1 \%)$ \\
PEP & $38(7.9 \%)$ \\
KIPP & $53(11.0 \%)$ \\
Boksmart & $5(1.0 \%)$ \\
Knäkontroll & $6(1.2 \%)$ \\
iSPRINT & $12(2.5 \%)$ \\
ACC & $14(2.9 \%)$ \\
N/A & $307(63.4 \%)$ \\
\hline
\end{tabular}

$11+=$ FIFA $11+$ Soccer Injury Prevention Program; 11+K = FIFA 11+ Kids Injury Prevention Program; $11+R=$ FIFA $11+$ Referees Injury Prevention Program; 11+S = FIFA 11+ Shoulder Injury Prevention Program for goalkeepers; GAA 15 = The Gaelic Athletic Association 15 Injury Prevention Program; PEP=Prevent injury and Enhance Performance Program; KIPP = Knee Injury Prevention Program; Boksmart = Boksmart Rugby Injury Prevention Program; Knäkontroll $=$ Knäkontroll Injury Prevention Program; iSPRINT = iSPRINT Injury Prevention Program; ACC = ACC SportSmart Program; N/A = None of the Above 
(Calculator.net, 2020). To achieve the target number of physiotherapists, all associations registered in the WPT were contacted to distribute the survey among their members.

Responses were organized in Microsoft Excel 2019 (Microsoft Corp. Redmond, Washington, United States). Data were analyzed using the Statistical Package for the Social Sciences (SPSS) version 24.0 (IBM Corp., Armonk, New York, United States). Descriptive statistics were presented as percentages. Chi-square test was used to compare Awareness and Implement among the different continents. However, ANOVA was used to compare the opinion score among the different continents. A p-value of 0.05 was set for statistical significance.

\section{Results}

This cross-sectional survey study was set to assess physiotherapists' awareness, implementation, and opinion of the 11 sports IPPs. The socio-demographic characteristics of the study participants are shown in Table 1 . More than half of the study respondents were females $55.6 \%, 24.8 \%$ were in the age group of $26-30$ years, and $43.4 \%$ were physiotherapists. European participants represented the highest proportion at $42.4 \%$, followed by $34.9 \%$ from Asia, while the lowest participation was from South America at 3.1\%. More than half (59.7\%) of the participants have an experience of $\leq 10$ years, $40.3 \%$ were specialized in sports medicine, and $33.1 \%$ had a master's degree.
Overall, all the assessed 11 prevention programs' awareness level was less than $50 \%$, the highest for the $11+$ at $45.2 \%$, followed by the $11+\mathrm{K}$ and KIPP at $21.1 \%$ for each, while the awareness levels about the remaining eight seven programs were $<20 \%$. For implementation, $22.3 \%$ of the participated physiotherapists were implementing the $11+$ program, while for the nine programs, the implementation level was less than $10 \%$ except the KIPP was at $11 \%$. Data are shown in Table 2

According to the world confederation for physiotherapy regions, the awareness level difference is shown in Table 3. Generally, there were statistically significant differences between the six regions in the awareness of $11+, 11+\mathrm{K}$, and KIPP. On the other hand, there wasn't a statistically significant difference between the physiotherapy confederation regions in the awareness of $11+\mathrm{R}, 11+\mathrm{S}$, GAA15, PEP, and Boksmart. Oceania showed the highest awareness of the $11+, 11+\mathrm{K}$ programs at $80 \%$, and $40 \%$, respectively. The $11+\mathrm{R}$ and $11+\mathrm{S}$ highest awareness level was $22.2 \%$ for each in Africa. For the GAA15, the highest awareness prevalence was among the South American at $13.3 \%$, while none of the Oceanian was aware of it.

For the difference in the implementation rates according to the different physiotherapy confederation regions, there was a statistically significant difference only in the $11+\mathrm{S}$, being the highest among the African physiotherapists at $14.8 \%$, and the lowest among the North, Central America,

Table 3. The difference in the awareness level according to the world confederation for physiotherapy regions

\begin{tabular}{|c|c|c|c|c|c|c|c|}
\hline Indicators & $\begin{array}{c}\text { Europe } \\
(n=205)\end{array}$ & $\begin{array}{l}\text { South American } \\
\quad(\mathrm{n}=15)\end{array}$ & $\begin{array}{c}\text { Asia } \\
(n=169)\end{array}$ & $\begin{array}{l}\text { Africa } \\
(n=27)\end{array}$ & $\begin{array}{c}\text { North, Central } \\
\text { America and } \\
\text { Caribbean } \\
(n=48)\end{array}$ & Oceania $(n=20)$ & p-value \\
\hline $11+$ & $\begin{array}{c}109 \\
(53.2 \%)\end{array}$ & $\begin{array}{c}6 \\
(40.0 \%)\end{array}$ & $\begin{array}{c}55 \\
(32.5 \%)\end{array}$ & $\begin{array}{c}12 \\
(44.4 \%)\end{array}$ & $\begin{array}{c}21 \\
(43.8 \%)\end{array}$ & $\begin{array}{c}16 \\
(80.0 \%)\end{array}$ & $<0.0001$ \\
\hline $11+\mathrm{K}$ & $\begin{array}{c}51 \\
(24.9 \%)\end{array}$ & $\begin{array}{c}2 \\
(13.3 \%)\end{array}$ & $\begin{array}{c}21 \\
(12.4 \%)\end{array}$ & $\begin{array}{c}7 \\
(25.9 \%)\end{array}$ & $\begin{array}{c}13 \\
(27.1 \%)\end{array}$ & $\begin{array}{c}8 \\
(40.0 \%)\end{array}$ & 0.008 \\
\hline $11+\mathrm{R}$ & $\begin{array}{c}27 \\
(13.2 \%)\end{array}$ & $\begin{array}{c}2 \\
(13.3 \%)\end{array}$ & $\begin{array}{c}16 \\
(9.5 \%)\end{array}$ & $\begin{array}{c}6 \\
(22.2 \%)\end{array}$ & $\begin{array}{c}4 \\
(8.3 \%)\end{array}$ & $\begin{array}{c}4 \\
(20.0 \%)\end{array}$ & 0.335 \\
\hline $11+S$ & $\begin{array}{c}26 \\
(12.7 \%)\end{array}$ & $\begin{array}{c}3 \\
(20.0 \%)\end{array}$ & $\begin{array}{c}30 \\
(17.8 \%)\end{array}$ & $\begin{array}{c}6 \\
(22.2 \%)\end{array}$ & $\begin{array}{c}9 \\
(18.8 \%)\end{array}$ & $\begin{array}{c}2 \\
(10.0 \%)\end{array}$ & 0.571 \\
\hline GAA15 & $\begin{array}{c}19 \\
(9.3 \%)\end{array}$ & $\begin{array}{c}2 \\
(13.3 \%)\end{array}$ & $\begin{array}{c}7 \\
(4.1 \%)\end{array}$ & $\begin{array}{c}2 \\
(7.4 \%)\end{array}$ & $\begin{array}{c}1 \\
(2.1 \%)\end{array}$ & $\begin{array}{c}0 \\
(0 \%)\end{array}$ & 0.138 \\
\hline PEP & $\begin{array}{c}24 \\
(11.7 \%)\end{array}$ & $\begin{array}{c}3 \\
(20.0 \%)\end{array}$ & $\begin{array}{c}25 \\
(14.8 \%)\end{array}$ & $\begin{array}{c}4 \\
(14.8 \%)\end{array}$ & $\begin{array}{c}7 \\
(14.6 \%)\end{array}$ & $\begin{array}{c}5 \\
(25.0 \%)\end{array}$ & 0.630 \\
\hline KIPP & $\begin{array}{c}31 \\
(15.1 \%)\end{array}$ & $\begin{array}{c}2 \\
(13.3 \%)\end{array}$ & $\begin{array}{c}47 \\
(27.8 \%)\end{array}$ & $\begin{array}{c}8 \\
(29.6 \%)\end{array}$ & $\begin{array}{c}7 \\
(14.6 \%)\end{array}$ & $\begin{array}{c}7 \\
(35.0 \%)\end{array}$ & 0.014 \\
\hline Boksmart & $\begin{array}{c}7 \\
(3.4 \%)\end{array}$ & $\begin{array}{c}1 \\
(6.7 \%)\end{array}$ & $\begin{array}{c}5 \\
(3.0 \%)\end{array}$ & $\begin{array}{c}0 \\
(0 \%)\end{array}$ & $\begin{array}{c}1 \\
(2.1 \%)\end{array}$ & $\begin{array}{c}1 \\
(5.0 \%)\end{array}$ & 0.851 \\
\hline Knäkontroll & $\begin{array}{c}4 \\
(2.0 \%)\end{array}$ & $\begin{array}{c}0 \\
(0 \%)\end{array}$ & $\begin{array}{c}6 \\
(3.6 \%)\end{array}$ & $\begin{array}{c}0 \\
(0 \%)\end{array}$ & $\begin{array}{c}1 \\
(2.1 \%)\end{array}$ & $\begin{array}{c}0 \\
(0 \%)\end{array}$ & 0.733 \\
\hline iSPRINT & $\begin{array}{c}5 \\
(2.4 \%) \\
\end{array}$ & $\begin{array}{c}0 \\
(0 \%) \\
\end{array}$ & $\begin{array}{c}5 \\
(3.0 \%) \\
\end{array}$ & $\begin{array}{c}3 \\
(11.1 \%) \\
\end{array}$ & $\begin{array}{c}4 \\
(8.3 \%)\end{array}$ & $\begin{array}{c}1 \\
(5.0 \%)\end{array}$ & 0.115 \\
\hline ACC & $\begin{array}{c}10 \\
(4.9 \%)\end{array}$ & $\begin{array}{c}0 \\
(0 \%)\end{array}$ & $\begin{array}{c}8 \\
(4.7 \%)\end{array}$ & $\begin{array}{c}1 \\
(3.7 \%)\end{array}$ & $\begin{array}{c}1 \\
(2.1 \%)\end{array}$ & $\begin{array}{c}3 \\
(15.0 \%)\end{array}$ & 0.286 \\
\hline
\end{tabular}

$11+=$ FIFA 11+ Soccer Injury Prevention Program; 11+K= FIFA 11+ Kids Injury Prevention Program; 11+R= FIFA 11+ Referees Injury Prevention Program; 11+S= FIFA 11+ Shoulder Injury Prevention Program for goalkeepers; GAA 15= The Gaelic Athletic Association 15 Injury Prevention Program; $\mathrm{PEP}=$ Prevent injury and Enhance Performance Program; KIPP=Knee Injury Prevention Program; Boksmart =Boksmart Rugby Injury Prevention Program; Knäkontroll =Knäkontroll Injury Prevention Program; iSPRINT =iSPRINT Injury Prevention Program; ACC =ACC SportSmart Program; N/A= None of the Above; \#: Chi-square test ${ }^{*} \mathrm{P}<0,05$ (significant) 
Table 4. The difference in the implementation level according to the world confederation for physiotherapy regions

\begin{tabular}{|c|c|c|c|c|c|c|c|}
\hline Indicators & $\begin{array}{c}\text { Europe } \\
(n=205)\end{array}$ & $\begin{array}{c}\text { South } \\
\text { American } \\
(\mathrm{n}=15)\end{array}$ & $\begin{array}{c}\text { Asia } \\
(n=169)\end{array}$ & $\begin{array}{l}\text { Africa } \\
(n=27)\end{array}$ & $\begin{array}{l}\text { North, Central } \\
\text { America and } \\
\text { Caribbean } \\
(n=48)\end{array}$ & $\begin{array}{l}\text { Oceania } \\
(n=20)\end{array}$ & p-value \\
\hline $11+$ & $\begin{array}{c}49 \\
(23.9 \%)\end{array}$ & $\begin{array}{c}4 \\
(26.7 \%)\end{array}$ & $\begin{array}{c}29 \\
(17.2 \%)\end{array}$ & $\begin{array}{c}10 \\
(37.0 \%)\end{array}$ & $\begin{array}{c}8 \\
(16.7 \%)\end{array}$ & $\begin{array}{c}8 \\
(40.0 \%)\end{array}$ & 0.053 \\
\hline $11+\mathrm{K}$ & $\begin{array}{c}13 \\
(6.3 \%)\end{array}$ & $\begin{array}{c}1 \\
(6.7 \%)\end{array}$ & $\begin{array}{c}13 \\
(7.7 \%)\end{array}$ & $\begin{array}{c}4 \\
(14.8 \%)\end{array}$ & $\begin{array}{c}2 \\
(4.2 \%)\end{array}$ & $\begin{array}{c}4 \\
(20.0 \%)\end{array}$ & 0.178 \\
\hline $11+\mathrm{R}$ & $\begin{array}{c}5 \\
(2.4 \%)\end{array}$ & $\begin{array}{c}1 \\
(6.7 \%)\end{array}$ & $\begin{array}{c}9 \\
(5.3 \%)\end{array}$ & $\begin{array}{c}2 \\
(7.4 \%)\end{array}$ & $\begin{array}{c}0 \\
(0 \%)\end{array}$ & $\begin{array}{c}1 \\
(5.0 \%)\end{array}$ & 0.359 \\
\hline $11+S$ & $\begin{array}{c}10 \\
(4.9 \%)\end{array}$ & $\begin{array}{c}2 \\
(13.3 \%)\end{array}$ & $\begin{array}{c}22 \\
(13.0 \%)\end{array}$ & $\begin{array}{c}4 \\
(14.8 \%)\end{array}$ & $\begin{array}{c}2 \\
(4.2 \%)\end{array}$ & $\begin{array}{c}1 \\
(5.0 \%)\end{array}$ & 0.047 \\
\hline GAA15 & $\begin{array}{c}10 \\
(4.9 \%)\end{array}$ & $\begin{array}{c}0 \\
(0 \%)\end{array}$ & $\begin{array}{c}5 \\
(3.0 \%)\end{array}$ & $\begin{array}{c}0 \\
(0 \%)\end{array}$ & $\begin{array}{c}0 \\
(0 \%)\end{array}$ & $\begin{array}{c}0 \\
(0 \%)\end{array}$ & 0.338 \\
\hline PEP & $\begin{array}{c}12 \\
(5.9 \%)\end{array}$ & $\begin{array}{c}1 \\
(6.7 \%)\end{array}$ & $\begin{array}{c}16 \\
(9.5 \%)\end{array}$ & $\begin{array}{c}1 \\
(3.7 \%)\end{array}$ & $\begin{array}{c}6 \\
(12.5 \%)\end{array}$ & $\begin{array}{c}2 \\
(10.0 \%)\end{array}$ & 0.553 \\
\hline KIPP & $\begin{array}{c}14 \\
(6.8 \%)\end{array}$ & $\begin{array}{c}0 \\
(0 \%)\end{array}$ & $\begin{array}{c}31 \\
(18.3 \%)\end{array}$ & $\begin{array}{c}5 \\
(18.5 \%)\end{array}$ & $\begin{array}{c}2 \\
(4.2 \%)\end{array}$ & $\begin{array}{c}1 \\
(5.0 \%)\end{array}$ & 0.002 \\
\hline Boksmart & $\begin{array}{c}3 \\
(1.5 \%)\end{array}$ & $\begin{array}{c}0 \\
(0 \%)\end{array}$ & $\begin{array}{c}2 \\
(1.2 \%)\end{array}$ & $\begin{array}{c}0 \\
(0 \%)\end{array}$ & $\begin{array}{c}0 \\
(0 \%)\end{array}$ & $\begin{array}{c}0 \\
(0 \%)\end{array}$ & 0.906 \\
\hline Knäkontroll & $\begin{array}{c}4 \\
(2.0 \%)\end{array}$ & $\begin{array}{c}0 \\
(0 \%)\end{array}$ & $\begin{array}{c}2 \\
(1.2 \%)\end{array}$ & $\begin{array}{c}0 \\
(0 \%)\end{array}$ & $\begin{array}{c}0 \\
(0 \%)\end{array}$ & $\begin{array}{c}0 \\
(0 \%)\end{array}$ & 0.816 \\
\hline iSPRINT & $\begin{array}{c}3 \\
(1.5 \%)\end{array}$ & $\begin{array}{c}0 \\
(0 \%)\end{array}$ & $\begin{array}{c}5 \\
(3.0 \%)\end{array}$ & $\begin{array}{c}2 \\
(7.4 \%)\end{array}$ & $\begin{array}{c}2 \\
(4.2 \%)\end{array}$ & $\begin{array}{c}0 \\
(0 \%)\end{array}$ & 0.392 \\
\hline ACC & $\begin{array}{c}5 \\
(2.4 \%)\end{array}$ & $\begin{array}{c}0 \\
(0 \%)\end{array}$ & $\begin{array}{c}7 \\
(4.1 \%)\end{array}$ & $\begin{array}{c}0 \\
(0 \%)\end{array}$ & $\begin{array}{c}1 \\
(2.1 \%)\end{array}$ & $\begin{array}{c}1 \\
(5.0 \%)\end{array}$ & 0.736 \\
\hline
\end{tabular}

$11+=$ FIFA 11+ Soccer Injury Prevention Program; 11+K = FIFA 11+ Kids Injury Prevention Program; 11+R = FIFA 11+ Referees Injury Prevention Program; $11+S=$ FIFA 11+ Shoulder Injury Prevention Program for goalkeepers; GAA 15 = The Gaelic Athletic Association 15 Injury Prevention Program; $\mathrm{PEP}=$ Prevent injury and Enhance Performance Program; KIPP = Knee Injury Prevention Program; Boksmart = Boksmart Rugby Injury Prevention Program; Knäkontroll = Knäkontroll Injury Prevention Program; iSPRINT = iSPRINT Injury Prevention Program; ACC = ACC SportSmart Program; N/A $=$ None of the Above; \#: Chi-square test ${ }^{*} \mathrm{P}<0,05$ (significant)

and Caribbean region at $4.2 \%$, with a p-value of 0.047 . Similarly, there was a significant difference in the KIPP program's implementation rate that ranged from $0 \%$ to $18.3 \%$ with a $\mathrm{p}$-value of 0.002 . A mention of the statistical analysis, statistically significant difference $(\mathrm{P}=0.05)$ was shown compared to the level of implementation of the 11+ IPP. Only $4.9 \%$ and $3 \%$ of Europe and Asia participants reported that they are implementing the GAA15. Simultaneously, none of the other regions knows about this IPP, with a non-significant difference of $(\mathrm{P}=0.33)$ mention in the statistical test. Regarding the other IPPs, the difference in the implementation rates wasn't statistically significant, as shown in Table 4.

Table 5 shows the opinion of the physiotherapists who implemented the IPPS in their practice. The mean $( \pm S D)$ of the effectiveness was the highest for the KIPP at 7.797 ( \pm $1.944)$ followed by the iSPRINT at $7.483( \pm 2.339)$, while it was the lowest for the GAA15 at $6.775( \pm 2.315)$. However, the difference between the scores of the effectiveness of the IPPS wasn't statistically significant.

\section{Discussion}

In a cross-sectional survey of 484 physiotherapists worldwide, the level of awareness, implementation, and effectiveness of IPPs was assessed, and the results revealed overall poor awareness and implementation levels. In addition, to the best of our knowledge, this is the first study to assess the awareness and implementation of IPPs among physiotherapists, globally, which makes it difficult to compare our results.

It was recently reported that the best IPP is the one that can and will be adopted and sustained by athletes, coaches, and sporting bodies (Emery \& Pasanen, 2019). IPPs are being used in real-world settings, but the challenge is implementing cost-effective injury prevention strategies in reallife circumstances (Timpka et al., 2006).

Being the highest, reaching a rate of $45.2 \%$ awareness of the $11+$ among physical therapist in the current study is lower than the level of awareness of the 11+ IPP among coaches of adolescent female football teams at 58\% (Donaldson et al., 2018), and lower than the level of awareness of lower limb IPPs among coaches of young football players in other international studies reaching more than $50 \%$ (Morgan et al., 2017; Norcross et al., 2016; O’Brien \& Finch, 2016). Additionally, a far higher awareness level at $80 \%$ was reported from coaches of Swedish amateur players of the 11 (a precursor to the 11+) program (Junge et al., 2011).

In the cluster-randomized controlled trial by O'Malley et al. (2017), they found that over eight weeks of training, the GAA 15 had a positive effect on neuromuscular control 
Table 5. The difference in opinion of the physiotherapist

\begin{tabular}{|c|c|c|c|c|c|c|c|c|c|c|c|}
\hline \multirow{3}{*}{ Opinion } & \multicolumn{11}{|c|}{ Programs } \\
\hline & $11+$ & $11+K$ & $11+R$ & $11+S$ & GAA15 & PEP & KIPP & Boksmart & Knäkontroll & iSPRINT & ACC \\
\hline & $\mathrm{n}=140$ & $n=68$ & $\mathrm{n}=45$ & $\mathrm{n}=\mathbf{5 7}$ & $\mathrm{n}=\mathbf{4 0}$ & $n=62$ & $\mathrm{n}=74$ & $\mathrm{n}=31$ & $\mathrm{n}=32$ & $\mathrm{n}=29$ & $\mathrm{n}=36$ \\
\hline \multirow[t]{2}{*}{1} & 1 & & & & 1 & & 1 & & & 1 & \\
\hline & 0.2 & & & & 0.2 & & 0.2 & & & 0.2 & \\
\hline \multirow[t]{2}{*}{2} & 3 & & 1 & 3 & 2 & 1 & & 1 & 2 & 1 & \\
\hline & 0.6 & & 0.2 & 0.6 & 0.4 & 0.2 & & 0.2 & 0.4 & 0.2 & \\
\hline \multirow[t]{2}{*}{3} & 4 & 5 & 5 & 1 & & 2 & 2 & & & & 1 \\
\hline & 0.8 & 1 & 1 & 0.2 & & 0.4 & 0.4 & & & & 0.2 \\
\hline \multirow[t]{2}{*}{4} & 6 & 3 & 1 & 4 & 2 & & 1 & 1 & 4 & 1 & 1 \\
\hline & 1.2 & 0.6 & 0.2 & 0.8 & 0.4 & & 0.2 & 0.2 & 0.8 & 0.2 & 0.2 \\
\hline \multirow[t]{2}{*}{5} & 14 & 8 & 3 & 4 & 6 & 6 & 5 & 5 & 2 & 2 & 4 \\
\hline & 2.9 & 1.7 & 0.6 & 0.8 & 1.2 & 1.2 & 1 & 1 & 0.4 & 0.4 & 0.8 \\
\hline \multirow[t]{2}{*}{6} & 20 & 10 & 6 & 5 & 6 & 10 & 7 & 3 & 3 & 2 & 6 \\
\hline & 4.1 & 2.1 & 1.2 & 1 & 1.2 & 2.1 & 1.4 & 0.6 & 0.6 & 0.4 & 1.2 \\
\hline \multirow[t]{2}{*}{7} & 33 & 14 & 6 & 13 & 8 & 10 & 12 & 5 & 7 & 5 & 7 \\
\hline & 6.8 & 2.9 & 1.2 & 2.7 & 1.7 & 2.1 & 2.5 & 1 & 1.4 & 1 & 1.4 \\
\hline \multirow[t]{2}{*}{8} & 30 & 9 & 6 & 12 & 6 & 14 & 15 & 4 & 3 & 6 & 6 \\
\hline & 6.2 & 1.9 & 1.2 & 2.5 & 1.2 & 2.9 & 3.1 & 0.8 & 0.6 & 1.2 & 1.2 \\
\hline \multirow[t]{2}{*}{9} & 9 & 5 & 5 & 5 & 2 & 8 & 15 & 5 & 3 & 5 & 4 \\
\hline & 1.9 & 1 & 1 & 1 & 0.4 & 1.7 & 3.3 & 1 & 0.6 & 1 & 0.8 \\
\hline \multirow[t]{2}{*}{10} & 20 & 14 & 12 & 10 & 7 & 11 & 16 & 7 & 8 & 6 & 7 \\
\hline & 4.1 & 2.9 & 2.5 & 2.1 & 1.4 & 2.3 & 3.3 & 1.4 & 1.7 & 1.2 & 1.4 \\
\hline Mean \pm SD & $\begin{array}{c}7.036 \pm \\
1.99\end{array}$ & $\begin{array}{c}7.088 \pm \\
2.128\end{array}$ & $\begin{array}{c}7.267 \pm \\
2.44\end{array}$ & $\begin{array}{c}7.14 \pm \\
2.191\end{array}$ & $\begin{array}{c}6.775 \pm \\
2.315\end{array}$ & $\begin{array}{c}7.452 \pm \\
1.914\end{array}$ & $\begin{array}{c}=7.797 \pm \\
1.944\end{array}$ & $7.452 \pm 2.142$ & $7.125 \pm 2.433$ & $\begin{array}{c}7.483 \pm \\
2.339\end{array}$ & $\begin{array}{c}7.389 \pm \\
1.902\end{array}$ \\
\hline Min. - Max. & $1-10$ & $3-10$ & $2-10$ & $2-10$ & $1-10$ & $2-10$ & $1-10$ & $2-10$ & $2-10$ & $1-10$ & $3-10$ \\
\hline $\mathrm{P}$-value & & & & & & & 0.405 & & & & \\
\hline
\end{tabular}

$11+=$ FIFA $11+$ Soccer Injury Prevention Program; $11+\mathrm{K}=$ FIFA 11+ Kids Injury Prevention Program; 11+R = FIFA 11+ Referees Injury Prevention Program; 11+S = FIFA 11+ Shoulder Injury Prevention Program for goalkeepers; GAA 15 = The Gaelic Athletic Association 15 Injury Prevention Program; PEP = Prevent injury and Enhance Performance Program; KIPP = Knee Injury Prevention Program; Boksmart $=$ Boksmart Rugby Injury Prevention Program; Knäkontroll = Knäkontroll Injury Prevention Program; iSPRINT = iSPRINT Injury Prevention Program; ACC = ACC SportSmart Program; $\mathrm{N} / \mathrm{A}=$ None of the Above; \#: One way ANOVA ${ }^{*} \mathrm{P}<0,05$ (significant)

among collegiate level in Gaelic football, regionally, and hurling male players, and supported the application and evaluation of the GAA 15 in other athletic groups. Despite this, an extremely low percentage of the physiotherapists' knowledge about this program, adding to that only half of them were implementing it $(6.4 \%$, and $3.1 \%$, respectively). Our finding agrees with a previously published study in 2017, which found that despite all coaches utilized selected components of IPPs, only 2 (out of 26) GAA coaches reported using the 'GAA 15 (Reilly \& Kipps, 2017). The low implementation rate in their study was explained by not getting enough support from the GAA and their county boards regarding injury prevention strategies.

It was stated that the PEP program should be considered as a part of women's soccer regular training as it helps in reducing the incidence of severe knee injuries (Rodríguez et al., 2018). Additionally, it was reported that KIPP significantly reduced the risk of non-contact lower limb injuries and over- use injuries in young amateur female football and basketball players (Herman et al., 2012). The awareness and implementation rates of such programs were very low in our study. The reason for that might be either low educational programs that are addressing them or might be due to those coaches or physiotherapists who don't believe in their effectiveness.

A study that addressed the BokSmart Safe Six IPP's effectiveness and implementation found that players' awareness about the program was associated with their coaches' awareness, and the awareness increased during the targeted marketing approach. Therefore, the authors concluded that the BokSmart Safe Six program was associated with minimal significant improvements in injury risk profiles (Sewry, 2018). The awareness level of the BokSmart (3.1\%) in the current study was lower than that what reported among coaches (78\%) and players (34\%) in the 2014-2016 South African rugby union youth week tournaments (Sewry et al., 2017). 
Our results revealed that even with extremely low percentages of physiotherapists' awareness of the IPPs, not all of them were implementing them. This supports the need to operationalize implementation efforts of sport IPPs in realworld contexts and provide a foundation for the ongoing adaptation and improvement of the successful programs. Like mobile applications and group training programs, online resources could help increase the awareness and implementation of such programs. Besides, and as with what has been suggested for increasing the awareness of the 11+ (Donaldson et al., 2018), using governing association communication channels like websites, e-newsletters, and social media platforms, as well as influences informal learning networks of opinion for leaders and peers could be effective in raising the awareness of the other IPPs among physiotherapists (Poulos \& Donaldson, 2012). Additionally, there is a need for further research studies addressing the causes behind low awareness and non-usage of the IPPs among physiotherapists worldwide.

The results of this study provide valuable information on the knowledge, implementation, and views of physiotherapists regarding IPPs globally. This information should be used to optimize access to education and the delivery of such programs.

The current study has some limitations, including the variable 'implement', and "effective", which were assessed in our study, are only facets. However, we assessed the level of awareness and implementation of IPPs in different countries, indicating the generalizability of the results, and this can be the base for future research in this area. A further research study should aim to define and allocate the different factors contributing to concepts such as program usage, and feasibility or suitability. In addition, as this study is crosssectional, the associations are temporary, and the effect of confounder variables is high. Other limitations include the effect of modification by clinical practice context and region, measurement bias, selection bias and type 1 error as well as generalizability.

\section{Conclusions}

Globally, physiotherapists have poor awareness and implementation levels of IPPs. Physiotherapists showed a positive score regarding the effectiveness of IPPS, especially the KIPP and the iSPRINT. There is a need for further efforts and research studies to increase the awareness and usage of IPPs among physiotherapists worldwide. From a present study, if physiotherapists need to increase their awareness and implementation of IPPs, it is recommended that IPPs should have further support, including media and resources.

\section{Acknowledgement}

The author(s) would like to thank all World Physiotherapy members' organizations for distributing the survey and Mr. Mansour Abdullah Alshehri NHMRC Centre of Clinical Research Excellence in Spinal Pain, Injury and Health, School of Health and Rehabilitation Sciences, University of Queensland, Brisbane, Queensland, Australia for his technical assistance, We express our gratitude to all physiotherapists who spent their valuable time participating in this study.

\section{Conflict of interest}

The authors declared no conflicts of interest.

\section{References}

Dhillon, H., Dhilllon, S., \& Dhillon, M. (2017). Current concepts in sports injury rehabilitation. Indian Journal of Orthopaedics, 51(5), 529.

https://doi.org/10.4103/ortho.IJOrtho_226_17

Habelt, S., Hasler, C. C., Steinbrück, K., \& Majewski, M. (2011). Sport injuries in adolescents. Orthopedic Reviews, 3(2), 18. https://doi.org/10.4081/or.2011.e18

Ekegren, C. L., Gabbe, B. J., \& Finch, C. F. (2016). Sports Injury Surveillance Systems: A Review of Methods and Data Quality. Sports Medicine, 46(1), 49-65. https://doi.org/10.1007/s40279-015-0410-z

Patel, D. R., Yamasaki, A., \& Brown, K. (2017). Epidemiology of sports-related musculoskeletal injuries in young athletes in United States. Translational Pediatrics, 6(3), 160-166. https://doi.org/10.21037/tp.2017.04.08

Soomro, N., Sanders, R., Hackett, D., Hubka, T., Ebrahimi, S., Freeston, J., \& Cobley, S. (2016). The Efficacy of Injury Prevention Programs in Adolescent Team Sports: A Meta-analysis. The American Journal of Sports Medicine, 44(9), 2415-2424. https://doi.org/10.1177/0363546515618372

Al Attar, W. S. A., Soomro, N., Pappas, E., Sinclair, P. J., \& Sanders, R. H. (2016). How Effective are F-MARC Injury Prevention Programs for Soccer Players? A Systematic Review and Meta-Analysis. Sports Medicine, 46(2), 205217. https://doi.org/10.1007/s40279-015-0404-x

Al Attar, W. S. A., Soomro, N., Pappas, E., Sinclair, P. J., \& Sanders, R. H. (2017). Adding a post-training FIFA 11+ exercise program to the pre-training FIFA 11+ injury prevention program reduces injury rates among male amateur soccer players: A cluster-randomised trial. Journal of Physiotherapy, 63(4), 235-242. https://doi.org/10.1016/j.jphys.2017.08.004

Sadigursky, D., Braid, J. A., De Lira, D. N. L., Machado, B. A. B., Carneiro, R. J. F., \& Colavolpe, P. O. (2017). The FIFA $11+$ injury prevention program for soccer players: A systematic review. BMC Sports Science, Medicine and Rehabilitation, 9(1), 18. https://doi.org/10.1186/s13102-017-0083-z

Al Attar, W. S. A., \& Alshehri, M. A. (2019). A meta-analysis of meta-analyses of the effectiveness of FIFA injury prevention programs in soccer. Scandinavian Journal of Medicine \& Science in Sports, 29(12), 1846-1855. https://doi.org/10.1111/sms.13535

Pomares-Noguera, C., Ayala, F., Robles-Palazón, F. J., Alomoto-Burneo, J. F., López-Valenciano, A., Elvira, J. L. L., Hernández-Sánchez, S., \& De Ste Croix, M. (2018). Training Effects of the FIFA 11+ Kids on Physical Performance in Youth Football Players: A Randomized Control Trial. Frontiers in Pediatrics, 6, 40. https://doi.org/10.3389/fped.2018.00040

Bizzini, M., \& Dvorak, J. (2015). FIFA 11+: An effective programme to prevent football injuries in various player groups worldwide - a narrative review. British Journal of 
Sports Medicine, 49(9), 577-579.

https://doi.org/10.1136/bjsports-2015-094765

O’Malley, E., Murphy, J. C., McCarthy Persson, U., Gissane, C., \& Blake, C. (2017). The Effects of the Gaelic Athletic Association 15 Training Program on Neuromuscular Outcomes in Gaelic Football and Hurling Players: A Randomized Cluster Trial. Journal of Strength and Conditioning Research, 31(8), 2119-2130. https://doi.org/10.1519/JSC.0000000000001564

GAA 15 [Internet]. Galic Atheltic Association. 2015 [cited 28 October 2020]. Available from: https://www.gaa.ie

Rahnama N. (2012). Preventing sport injuries: improving performance. International Journal of Preventive Medicine, 7, 3(3).

Santa Monica Sports Medicine Research Foundation (2011) [Internet]. The PEP program: Prevent injury and enhance performance. [cited 19 November 2020]. Available from: https://www.aclstudygroup.com/pdf/pep-program.pdf

Yarsiasat J, Sumannont S, Manimmanakorn N, Srilamarth S. (2019). Effectiveness of the Prevent Injury Enhance Performance (PEP) Training Program in reducing injury incidence rates among adolescent female Sepak takraw players: a randomised controlled trial. Journal of the Medical Association of Thailand,1, 102(6), 98.

LaBella, C. R., Huxford, M. R., Grissom, J., Kim, K.-Y., Peng, J., \& Christoffel, K. K. (2011). Effect of Neuromuscular Warm-up on Injuries in Female Soccer and Basketball Athletes in Urban Public High Schools: Cluster Randomized Controlled Trial. Archives of Pediatrics \& Adolescent Medicine, 165(11), 1033.

https://doi.org/10.1001/archpediatrics.2011.168

Sewry, N., Brown, J., Lambert, M., Van Mechelen, W., \& Verhagen, E. (2017). The efficacy of the BokSmart Safe Six exercise-based intervention on injury risk profiles in healthy active adults: A feasibility study. Journal of Science and Medicine in Sport, 20, 61.

https://doi.org/10.1016/j.jsams.2017.09.316

Sewry, N., Verhagen, E., Lambert, M., van Mechelen, W., \& Brown, J. (2017). Players' and coaches' knowledge and awareness of the BokSmart Safe Six injury prevention programme: An ecological cross-sectional questionnaire study. BMJ Open, 7(11), e018575. https://doi.org/10.1136/bmjopen-2017-018575

Hägglund, M., Waldén, M., \& Atroshi, I. (2009). Preventing knee injuries in adolescent female football players - design of a cluster randomized controlled trial [NCT00894595]. BMC Musculoskeletal Disorders, 10(1), 75. https://doi.org/10.1186/1471-2474-10-75

Voight T, Esculier D. (2019). Abstracts From the 3rd World Congress of Sports Physical Therapy. International Journal of Sports Physical Therapy, 14(6), 1-28.

ACC SportSmart [Internet]. Websites.sportstg.com. 2016 [cited 21 November 2020]. Available from: https://websites.sportstg.com/get_file.cgi?id=2486735

News and views [Internet]. World Physiotherapy. 2020 [cited 10 July 2020]. Available from: https://www.wcpt.org/news?page $=7$

Calculator s. Sample Size Calculator [Internet]. Calculator.net. 2020 [cited 10 July 2020].
Emery, C. A., \& Pasanen, K. (2019). Current trends in sport injury prevention. Best Practice \& Research Clinical Rheumatology, 33(1), 3-15. https://doi.org/10.1016/j.berh.2019.02.009

Timpka, T., Ekstrand, J., \& Svanström, L. (2006). From Sports Injury Prevention to Safety Promotion in Sports. Sports Medicine, 36(9), 733-745. https://doi.org/10.2165/00007256-200636090-00002

Donaldson, A., Callaghan, A., Bizzini, M., Jowett, A., Keyzer, P., \& Nicholson, M. (2018). Awareness and use of the 11+ injury prevention program among coaches of adolescent female football teams. International Journal of Sports Science \& Coaching, 13(6), 929-938. https://doi.org/10.1177/1747954118787654

Morgan, E. A., Johnson, S. T., Bovbjerg, V. E., \& Norcross, M. F. (2018). Associations between player age and club soccer coaches' perceptions of injury risk and lower extremity injury prevention program use. International Journal of Sports Science \& Coaching, 13(1), 122-128. https://doi.org/10.1177/1747954117707480

Norcross, M. F., Johnson, S. T., Bovbjerg, V. E., Koester, M. C., \& Hoffman, M. A. (2016). Factors influencing high school coaches' adoption of injury prevention programs. Journal of Science and Medicine in Sport, 19(4), 299-304. https://doi.org/10.1016/j.jsams.2015.03.009

O'Brien, J., \& Finch, C. F. (2016). Injury prevention exercise programmes in professional youth soccer: Understanding the perceptions of programme deliverers. BMJ Open Sport \& Exercise Medicine, 2(1), e000075. https://doi.org/10.1136/bmjsem-2015-000075

Junge, A., Lamprecht, M., Stamm, H., Hasler, H., Bizzini, M., Tschopp, M., Reuter, H., Wyss, H., Chilvers, C., \& Dvorak, J. (2011). Countrywide Campaign to Prevent Soccer Injuries in Swiss Amateur Players. The American Journal of Sports Medicine, 39(1), 57-63. https://doi.org/10.1177/0363546510377424

Reilly, J., \& Kipps, C. (2017). The Implementation and Adoption of the Injury Prevention Exercise Programme GAA 15 in Gaelic Football Club Teams in the Counties of Mayo and London. British Journal of Sports Medicine, 51(4), 377.2377. https://doi.org/10.1136/bjsports-2016-097372.237

Rodriguez C, Echegoyen S, Aoyama T. (2018). The effects of "Prevent Injury and Enhance Performance Program" in a female soccer team. Journal of Sports Medicine and Physical Fitness, 58(5), 659-3. https://doi.org/10.23736/S0022-4707.17.07024-4

Herman, K., Barton, C., Malliaras, P., \& Morrissey, D. (2012). The effectiveness of neuromuscular warm-up strategies, that require no additional equipment, for preventing lower limb injuries during sports participation: A systematic review. BMC Medicine, 10(1), 75. https://doi.org/10.1186/1741-7015-10-75

Poulos, R. G., \& Donaldson, A. (2012). Is sports safety policy being translated into practice: What can be learnt from the Australian rugby union Mayday procedure? British Journal of Sports Medicine, 46(8), 585-590. https://doi.org/10.1136/bjsports-2011-090469 


\title{
ОБІЗНАНІСТЬ ЩОДО ІСНУЮЧИХ ПРОГРАМ ПРОФІЛАКТИКИ СПОРТИВНИХ ТРАВМ ТА ЇХ ВИКОРИСТАННЯ ФІЗІОТЕРАПЕВТАМИ В УСЬOMУ CBITI
}

\author{
Весам Салех А. Аль Аттар ${ }^{1,2,3 \mathrm{ABCDE}}$, Сауд Аларіфі ${ }^{4 \mathrm{CD}}$, Хуссейн Гулам $^{5 \mathrm{CD}}$, \\ Самір Ямані ${ }^{1 B D}$, Эйад Альхарбі ${ }^{18 D}$, Маджед Альджабрі ${ }^{1 B D}$, Росс Х. Сандерс ${ }^{\text {AD }}$ \\ ${ }^{1}$ Університет Умм Аль Кура \\ ${ }^{2}$ Університет Сіднея \\ ${ }^{3}$ Базельський університет \\ ${ }^{4}$ Медичне містечко короля Абдулазіза \\ ${ }^{5}$ Наджранський університет
}

Авторський вклад: А - дизайн дослідження; В - збір даних; C - статаналіз; D - підготовка рукопису; Е - збір коштів

Реферат. Стаття: 10 с., 5 табл., 35 джерел.

Мета дослідження. Фізіотерапевтів навчають запобіганню, оцінці та реабілітації після всіх видів травм, включаючи спортивні. Мета фізіотерапевта - це переконатися, що спортсмен знаходиться в оптимальній формі для занять спортом з мінімальним ризиком отримання травми. Це дослідження має на меті оцінити обізнаність, рівень впровадження та погляди фізіотерапевтів на програми профілактики спортивних травм (ППТ) з міжнародної точки зору.

Матеріали та методи. Анкета для самостійного заповнення була розроблена та поширена серед фізіотерапевтів в усьому світі за допомогою членських організацій Всесвітньої фізіотерапії. Дослідження було орієнтоване на фізіотерапевтів на міжнародному рівні. У дослідженні взя- ли участь 484 фізіотерапевти, зокрема чоловіки - 44,4\% та жінки $-55,6 \%$.

Результати. Всього 287 (59,3\%) учасників були обізнані про діючі ППТ, 177 (36,6\%) впроваджували їх у своїй поточній практиці. Учасники, які впроваджували програми, повідомили про позитивну думку щодо їх ефективності 3 оцінкою 7,3 $\pm 2,11$ з 10 .

Висновки. В усьому світі фізіотерапевти мають середню обізнаність та низький рівень впровадження ППТ. Фізіотерапевти дали позитивну оцінку ефективності ППТ, особливо KIPP та iSPRINT.

Ключові слова: спортсмени, травми, спорт, фізіотерапія, опитування та анкетування, інтернаціональність.

\section{Information about the authors:}

Wesam Saleh A. Al Attar, PT, MSc, PhD: wsattar@uqu.edu.sa; https://orcid.org/0000-0003-1907-4539; Department of Physiotherapy, Faculty of Applied Medical Sciences, Umm Al Qura University, PO Box: 715, Makkah, 21955, Saudi Arabia. Discipline of Exercise and Sport Science, Faculty of Medicine and Health Sciences, The University of Sydney, Australia; Department of Sport, Exercise and Health, Faculty of Medicine, University of Basel, Basel, Switzerland.

Saud Alarifi, PT, MSc, PhD: Arifis@ngha.med.sa; https://orcid.org/0000-0002-3826-0292; Department of Physiotherapy, King Abdulaziz Medical City, Riyadh, Saudi Arabia.

Hussain Ghulam, PT, MSc, PhD: hsghulam@nu.edu.sa; https://orcid.org/0000-0003-3525-4767; Department of Physiotherapy, Faculty of Applied Medical Sciences, Najran University, Najran, Saudi Arabia.

Sameer Yamani, PT, MSc: s44181087@st.uqu.edu.sa; https://orcid.org/0000-0003-2178-8370; Department of Physiotherapy, Faculty of Applied Medical Sciences, Umm Al Qura University, PO Box: 715, Makkah, 21955, Saudi Arabia.

Eyad Alharbi, PT, MSc: s44180839@st.uqu.edu.sa; https://orcid.org/0000-0002-2962-0292; Department of Physiotherapy, Faculty of Applied Medical Sciences, Umm Al Qura University, PO Box: 715, Makkah, 21955, Saudi Arabia.

Majed Aljabri, PT, MSc: s44180650@st.uqu.edu.sa; https://orcid.org/0000-0002-9381-0760; Department of Physiotherapy, Faculty of Applied Medical Sciences, Umm Al Qura University, PO Box: 715, Makkah, 21955, Saudi Arabia.

Ross H. Sanders, PhD: ross.sanders@sydney.edu.au; https://orcid.org/0000-0003-0489-3048; Discipline of Exercise and Sport Science, Faculty of Medicine and Health Sciences, The University of Sydney, Australia.

Cite this article as: Al Attar, W.S.A., Alarifi, S., Ghulam, H., Yamani, S., Alharbi, E., Aljabri, M., \& Sanders, R.H. (2021). Awareness and Use of Current Sports Injury Prevention Programs among Physiotherapists Worldwide. Teoriâ ta Metodika Fizičnogo Vihovannâ, 21(4), 365-374. https://doi.org/10.17309/tmfv.2021.4.12

Received: 03.10.2021. Accepted: 06.11.2021. Published: 25.12.2021

This work is licensed under a Creative Commons Attribution 4.0 International License (http://creativecommons.org/licenses/by/4.0). 